\title{
The role of pregnancy-associated plasma protein-a level in the first trimester of pregnancy and clinical outcome in an urban referral centre
}

\author{
Lavanya T.*, Premalatha R., Nandita A. Thakkar, Latha Jawahar, Priya Kannappa \\ Rajendran, Geethanjali E., Swetha V. Rajan
}

Department of Obstetrics and Gynecology, Mehta Multispeciality Hospitals India Pvt. Ltd, Chetpet, Chennai, India

Received: 28 June 2019

Accepted: 11 September 2019

\section{*Correspondence:}

Dr. Lavanya T.,

E-mail: drlavanya16@gmail.com.

Copyright: (c) the author(s), publisher and licensee Medip Academy. This is an open-access article distributed under the terms of the Creative Commons Attribution Non-Commercial License, which permits unrestricted non-commercial use, distribution, and reproduction in any medium, provided the original work is properly cited.

\begin{abstract}
Background: Estimation of serum PAPP-A levels studied predictability for adverse perinatal outcome. This case control study tries to establish the association between low PAPP-A levels among the pregnant woman and adverse maternal foetal outcome.

Methods: This is an case-control study during 2017-2018 in the women delivered at Department of OBG at Mehta Hospitals. Women delivered in the labour room had a first trimester screening of PAPP-A level were explained, taken informed consent, questionnaire which include detailed antenatal history, mode of delivery and baby data. Depending upon outcome, the subjects are classified as case group or control group, out of the study sample of 264 subjects, 88 patients who had complications were taken as cases and 176 patients with no complications taken as control were undertaken.

Results: Low PAPP-A level $(<0.5 \mathrm{MoM})$ showed high incidence of PIH and preeclampsia, followed by IUGR and Preterm. PAPP-A level $>0.5 \mathrm{MoM}$, normal outcome is more than the adverse outcome. The difference in the PAPP-A levels is statistically significant. In women with low PAPP A level, low birth weight found statistically significant when compared with <0.5 PAPP A level. The sensitivity of PAPP A levels in identifying the complicated outcomes was $17.04 \%$. The specificity was $98.85 \%$. The positive predictive value of predicting the complications was $88.23 \%$ and negative predictive value of $70.44 \%$.

Conclusions: The low PAPP-A levels confirmed during first trimester of pregnancy is associated with adverse maternal and foetal outcome such as PIH, preeclampsia, preterm, IUGR and LBW.
\end{abstract}

Keywords: Free beta HCG, IUGR, NT, PAPP-A, Preterm labour, Preeclampsia

\section{INTRODUCTION}

First trimester in pregnancy is considered as crucial period of pregnancy as both growth and differentiation of foetus takes place. Early identification of abnormalities helps in effective management of the pregnancy. ${ }^{1-3}$ In the first trimester of pregnancy, biochemical markers derived from placenta, pregnancy-associated plasma protein A (PAPP-A) and beta-human chorionic gonadotropin (beta-hCG), are widely used together with ultrasound measurement of nuchal translucency (NT) thickness as part of screening programmes of chromosomal abnormalities. ${ }^{4,5}$ Various studies have been done in the past to study the usefulness of PAPP-A in predicting the adverse outcomes of later stages of the pregnancy. ${ }^{6-9}$

Apart from the chromosomal abnormality, women undergoing biochemical screening and are found to have apparently lower PAPP-A levels in the first trimester are increasingly considered as being at increased risk for other 
pregnancy related complications. Such adverse outcomes and related complications include miscarriage, preterm delivery, small-for-gestational-age (SGA) infant, neonatal intensive care unit (NICU) admission, and stillbirth. ${ }^{10-16}$

The association between PAPP-A or beta-hCG levels with various abnormal obstetric outcomes has been described by the fact that both hormones are produced in the placenta immediately after implantation, and reduced levels may possibly reflect abnormal placentation. ${ }^{17-20}$ This in turn, account for adverse obstetric and neonatal outcomes.

A low PAPP-A is descriptive of poor early placentation and may result in adverse pregnancy outcomes such as ${ }^{21,22}$

- Mid trimester miscarriage

- Fetal growth restriction

- Intrauterine fetal death

- Preterm birth

- Preeclampsia

- Stillbirth.

Abnormal levels of maternal serum analyte and measurement of fetus during the first trimester screening can be a predictor for not only certain chromosomal disorders and fetal anomalies but also for certain specific complications of pregnancy.

Especially, decreased maternal serum pregnancy-associated plasma protein-A (PAPP-A), during 11-13 weeks of gestation, is associated with adverse outcomes of the pregnancy like stillbirth, preterm birth, intrauterine growth restriction (IUGR), and pre-eclampsia in chromosomally normal fetuses, while a increased nuchal translucency is associated with certain specific structural abnormalities and genetic syndromes. ${ }^{23-31} \mathrm{~A}$ low or decreased level of PAPP$\mathrm{A}$ is defined as a maternal serum PAPP-A value $<0.4$ MOM, with increased risk of adverse obstetrical outcomes noted below this level. ${ }^{32,33}$

Although data are few and often conflicting with each other, a review of literature on PAPP - A reveals some evidence of an association between low PAPP-A levels in the first trimester and adverse pregnancy outcomes including preterm delivery, hypertensive disorders of pregnancy, SGA, IUGR and stillbirth in low-risk populations. $^{34-36}$ Studies available in literature from 2008 conclude that a PAPP-A level below the fifth percentile (outside two S.D.) is significantly associated with an increased chance of spontaneous abortion before the age of viability $(\mathrm{p}<0.05)$.

Studies with bigger sample size studying the relationship between adverse pregnancy outcomes and decreased PAPP-A levels will require capture of placental pathology to test the hypothesis that abnormal placentation is the reason. ${ }^{24}$ Clinically, low PAPP-A levels detected in the context of normal fetal aneuploidy screening is debatable, pregnant patients with such results should be counselled that at present no strong evidence exists to justify on-going ultrasound surveillance.

\section{METHODS}

This was an observational study/case control study done at Mehta Multispeciality Hospitals India Pvt. Ltd. from August 2017 to May 2018. Women delivered at the Department of OBG at Mehta Multispeciality Hospitals India Pvt. Ltd. were included in the study.

\section{Inclusion criteria}

- Delivered women who were screened for PAPP-A levels in the first trimester.

\section{Exclusion criteria}

- Multiple child birth.

\section{Operational definitions}

- Case: Adverse maternal and fetal outcome.

- Control: Normal maternal and fetal outcome.

- Adverse maternal and foetal outcomes.

- $\quad$ Preterm birth: Preterm birth is defined as birth before 37 weeks.

- Pregnancy induced hypertension; defined as development of hypertension to the extent of 140/90 $\mathrm{mmHg}$ or more with proteinuria after the 20 weeks. of pregnancy in previously normotensive and non proteinuric patient.

- $\quad$ Fetal growth restriction: designed to identify fetuses with estimated weight below the $10^{\text {th }}$ percentile for the gestation ages.

- $\quad$ Stillbirth: Defined as fetal death occurring after 20weeks of pregnancy or fetal weight more than $500 \mathrm{~g}$.

\section{Confounding factors}

- Urinary tract infection: Urinary tract infection in the pregnancy.

- Polyhydramnios: Excessive amniotic fluid.

- Incompetent cervix: Painless cervical dilatation in the second trimester.

- Chronic Hypertension: BP >140/90mmHg before pregnancy (or) diagnosed before 20weeks.

- Severe Anaemia: Haemoglobin concentration less than $7 \mathrm{~g} / \mathrm{dL}$ in the pregnant women.

- Cardiac disease: New York Heart Association based class3 and class 4 .

- Gestational Diabetes: Diabetes diagnosed during pregnancy.

- Overt diabetes: Diabetes diagnosed before pregnancy.

- PAPP-A Level:
$>$ Normal $>0.5 \mathrm{MoM}$
$>$ Low $\leq 0.5$ MoM. 


\section{Sample size}

With reference from Gordon. C.S. Smith,et al study, considering the proportion of adverse pregnancy outcome among women with normal PAPP-A level to be $29 \%$ and among women with normal PAPP-A level to be $12 \%$ with ratio of both groups as 1:2 at $95 \%$ confidence levels) and $80 \%$ power, the sample size is calculated as

$$
N=\frac{(\mathrm{r}+1) * \mathrm{p} *(1-\mathrm{p}) *\left(Z_{\alpha}+Z_{\beta}\right)^{2}}{\mathrm{r}} \frac{{ }^{2}}{(p 1-p 2)^{2}}
$$

Here $\mathrm{Z}_{\alpha}=1.96, \mathrm{Z}_{\beta}=0.84, \mathrm{p} 1=0.29, \mathrm{p} 2=0.12, \mathrm{p}=(\mathrm{p} 1+\mathrm{p} 2) / 2=$ $0.205, \mathrm{r}=2$

With the above formula, $\mathrm{N}=88 .^{7}$ The sample size for cases is estimated to be 88 and control to be 176 and totally the study sample is 264 subjects. Case followed within one week control taken.

\section{Study Method}

Women delivered in the labour room who had a first trimester screening of PAPP-A level were explained about the study after getting informed consent (Annexure II and III), reviewed for antenatal card,questionnaire which include detailed antenatal history of mode of delivery and details of the baby data enter into the annexure II. Case review was done with same person. Depending upon outcome, the subjects are classified as case group or control group.

\section{Statistical analysis}

The collected data were entered in Microsoft Excel 2013 and exported to SPSS v21 for analysis. The frequency distributions of all variables were expressed in percentages and the association between pregnancy outcomes and low PAPP-A level by Chi square test. The strength of association is expressed as odds ratio with $95 \%$ Confidence Interval. The predictive efficiency of PAPP-A is calculated by positive predictive value. $\mathrm{P}<0.05$ is considered for the statistical significance.

\section{RESULTS}

The study had revealed that there is no statistically significant association of factors such as maternal age, parity, marital history, family history and previous obstetric complication between the case and control groups.

Mode of conception (ART, IUI, Ovulation induction) than spontaneous conception significantly represented more number in case group compared to control group which is proved statistically. In case group, $78 \%$ had deliveries $<37$ weeks and $18 \%$ had term deliveries and the difference was statistically significant with the control group. In the study there is high incidence of PIH and pre-eclampsia (17\%), followed by preterm $(9.1 \%)$ and IUGR $(6.8 \%)$ with normal outcomes in $66.7 \%$. In the study out of 264 deliveries,
LSCS rate is higher compared to the normal delivery. The percentage of normal delivery is $28 \%$, while LSCS deliveries were $72 \%$. In the study Low PAPP-A level $(<0.5 \mathrm{MoM})$ shows high incidence of PIH and PreEclampsia, followed by IUGR and Preterm. PAPP-A level $>0.5 \mathrm{MoM}$, normal outcome is more than the adverse outcome. The difference in the PAPP-A levels is statistically significant.

Women with low PAPP-A level, low birth weight found statistically significant when compared with $\leq 0.5$ PAPP A level. NICU admission and APGAR not found to be statistically significant. LBW babies prevalent high in low PAPP A level. In the present study, the sensitivity of PAPP A levels in identifying the complicated outcomes was $17.04 \%$ and the specificity was $98.85 \%$. The positive predictive value of predicting the complications was $88.23 \%$ and negative predictive value of $70.44 \%$.

\section{DISCUSSION}

This was a case -control study done in delivered women who were screened for PAPP-A levels in the first trimester, they were included.

When compared with the prospective cohort study done by Smith et al, to assess the risk of adverse perinatal outcome among 8839 women showed that, Women with a pregnancy-associated plasma protein A (PAPP-A) had an increased risk of intrauterine growth restriction with adjusted odds ratio of 2.9; (95\% confidence interval (CI), 2.0-4.1), extremely premature delivery with adjusted odds ratio of $2.9(95 \% \mathrm{CI}, 1.6-5.5)$, moderately premature delivery with adjusted odds ratio of $2.4(95 \%$ CI $1.7-3.5)$, preeclampsia with adjusted odds ratio of $2.3(95 \% \mathrm{CI}, 1.6-$ $3.3)$, and stillbirth with adjusted odds ratio of $3.6(95 \% \mathrm{CI}$, 1.2-11.0) (Table 1). ${ }^{38}$

Table1: Outcome compared with low PAPP-A level.

\begin{tabular}{|lll|}
\hline $\begin{array}{l}\text { Outcome } \\
\text { compared with } \\
\text { low PAPP-A } \\
\text { level }\end{array}$ & Present study & Smith et al \\
\hline IUGR & $33.46(5.9-189.4) 47$ & $2.9(2.0-4.1)$ \\
\hline Preterm & $7.9(1.1-58.9) 29.4$ & $2.4(1.6-5.5)$ \\
\hline $\begin{array}{l}\text { Pre eclampsia } \\
\text { /PIH }\end{array}$ & $18.8(3.8-92.2) 11.7$ & $2.3(1.6-3.3)$ \\
\hline
\end{tabular}

A population-based screening study (The FASTER Trial) by Dugoff et al was done, who studied first-trimester maternal serum PAPP-A and free-beta subunit human chorionic gonadotropin concentrations and nuchal translucency for its association with obstetric complications. They revealed that women with pregnancyassociated plasma protein $A$ of $\leq 5^{\text {th }}$ percentile were significantly more likely to develop spontaneous fetal loss at $\leq 24$ gestational weeks, gestational hypertension, low birth weight, preeclampsia, preterm birth $(\mathrm{p}<0.001)$ and preterm premature rupture of membranes, stillbirth, and 
placental abruption $(\mathrm{p}<0.02) .^{2}$ Almost all findings of this study were supported by the findings from the present study but we couldn't take account of fetal loss $\leq 24$ gestational weeks since it was a case control study which considered those subjects came for delivery. ${ }^{39}$

In the Indian population study conducted by Jyoti Malik et al, to relate pregnancy outcome to PAPP-A level in the first trimester of pregnancy 524 antenatal patients were included in the study and found 452 patients were with normal PAPP-A level and 72 patients were in low PAPP-A level.

Out of 72 patients, 32(44\%) patients developed preterm labour and 11(15\%) patients developed foetal growth retardation and $16(22 \%)$ patients developed pregnancy induced hypertension. The obstetric outcome of patients with normal PAPP-A level was fairly uneventful as compared to others with a low PAPP-A level. ${ }^{40}$

The prevalence of all complications among low PAPP-A level subjects in the study was $88 \%$ which was close to Jyoti Malik et al study which showed $83 \%$. There were mild differences in the individual complication prevalence in low PAPP-A level subjects which is dependent on the subjects. In the study, the sensitivity of PAPP A levels in identifying the pregnancy complications was $17.04 \%$ and the specificity was $98.85 \%$. The positive predictive value of predicting the complications was $88.23 \%$ and negative predictive value of $70.44 \%$ of the population (Table 2 ).

Table 2: Validity of low PAPP-A levels.

\begin{tabular}{|lll|}
\hline Validity of low PAPP-A & $\begin{array}{l}\text { Present } \\
\text { study }\end{array}$ & $\begin{array}{l}\text { Piyathida } \\
\text { Pummara et al }\end{array}$ \\
\hline Sensitivity & $17.04 \%$ & $20 \%$ \\
\hline Specificity & $98.85 \%$ & $91.40 \%$ \\
\hline Positive predictive value & $88.23 \%$ & $17.90 \%$ \\
\hline $\begin{array}{l}\text { Negative predictive } \\
\text { value }\end{array}$ & $70.44 \%$ & $92.40 \%$ \\
\hline
\end{tabular}

\section{CONCLUSION}

The low PAPP-A levels confirmed during first trimester of pregnancy is associated with adverse maternal and foetal outcome such as PIH, preeclampsia, preterm, IUGR and LBW.

\section{ACKNOWLEDGMENTS}

Authors would like to thank the entire pregnant mother and their baby, Dr. Pavani, Dr. Hanifa, Dr. Nesri, Dr. Sivakamini, Dr. Balaji for their support during study.

Funding: No funding sources Conflict of interest: None declared Ethical approval: The study was approved by the Institutional Ethics Committee

\section{REFERENCES}

1. Gude NM, Roberts CT, Kalionis B, King RG. Growth and function of the normal human placenta. Thromb Res. 2004;114(5-6):397-407.

2. Garnica AD, Chan WY. The role of the placenta in fetal nutrition and growth. J Am Coll Nutr. 1996;15(3):206-22.

3. Hay WW. Placental transport of nutrients to the fetus. Horm Res. 1994;42(4-5):215-22.

4. Gagnon A, Wilson RD, Audibert F. Obstetrical complications associated with abnormal maternal serum markers analytes. J Obstet Gynaecol Can. 2008;30:918-49.

5. Goetzl L. Adverse pregnancy outcomes after abnormal first-trimester screening for aneuploidy. Clin Lab Med. 2010;30(3):613-28.

6. Saruhan Z, Ozekinci M, Simsek M, Mendilcioglu I. Association of first trimester low PAPP-A with adverse pregnancy outcomes. Clin Exp Obstet Gynecol. 2012;39(2):225-8.

7. Spencer CA, Allen VM, Flowerdew G, Dooley K, Dodds L. Low levels of maternal serum PAPP-A in early pregnancy and the risk of adverse outcomes. Prenat Diagn. 2008;28(11):1029-36.

8. Yaron Y, Heifetz S, Ochshorn Y, Lehavi O, Orr-Urtreger A. Decreased first trimester PAPP-A is a predictor of adverse pregnancy outcome. Prenat Diagn. 2002;22:778-82.

9. Scott F, Coates A, McLennan A. Pregnancy outcome in the setting of extremely low first trimester PAPP-A levels. Aust NZJ Obstet Gynaecol. 2009;49:258-62.

10. Marttala J, Peuhkurinen S, Laitinen P, Gissler M, Nieminen $\mathrm{P}$, Ryynanen M. Low maternal PAPP-A is associated with small-for-gestational age newborns and stillbirths. Acta Obstet Gynecol Scand. 2010;89(9):1226-8.

11. Kirkegaard I, Uldbjerg N, Henriksen TB. PAPP-A and free $\beta-h C G$ in relation to admission to neonatal intensive care unit and neonatal disease. Prenat Diagn. 2011;31:1169-75.

12. Carbone JF, Tuuli MG, Bradshaw R, Liebsch J, Odibo AO. Efficiency of first-trimester growth restriction and low pregnancy-associated plasma protein-A in predicting small for gestational age at delivery. Prenat Diagn. 2012;32(8):724-9.

13. Fox NS, Chasen ST. First trimester pregnancy associated plasma protein - A as a marker for poor pregnancy outcome in patients with early-onset fetal growth restriction. Prenat Diagn. 2009;29:1244-8.

14. Peterson SE, Simhan HN. First-trimester pregnancyassociated plasma protein $\mathrm{A}$ and subsequent abnormalities of fetal growth. Am J Obstet Gynecol. 2008;198(5):43-5.

15. Pummara $\mathrm{P}$, Tongsong $\mathrm{T}$, Wanapirak C, Sirichotiyakul S, Luewan S. Association of first-trimester pregnancyassociated plasma protein A levels and idiopathic preterm delivery: A population-based screening study. J Obstet Gynaecol. 2016;55:72-5.

16. Bell AW, Hay WW, Ehrhardt RA. Placental transport of nutrients and its implications for fetal growth. J Reprod Fertil Suppl. 1999;54:401-10.

17. Costa MA. The endocrine function of human placenta: an overview. Reprod Biomed Online. 2016;32(1):14-43.

18. Mesdaghinia E, Behrashi M, Saeidi A, Kalahroodi MA, Sehat M. Association between PAPP-A and placental thickness. Int J Reprod Bio Med. 2016;14(6):421-6. 
19. Proctor LK, Toal M, Keating S, Chitayat D, Okun N, Windrim RC, Smith GC, Kingdom JC. Placental size and the prediction of severe early-onset intrauterine growth restriction in women with low pregnancy-associated plasma protein-A. Ultrasound Obstet Gynaecol. 2009;34(3):274-82.

20. Chakraborty C, Gleeson LM, McKinnon T, Lala PK. Regulation of human trophoblast migration and invasiveness. Can J Physiol Pharmacol. 2002;80(2):116-24.

21. Kaufmann P, Black S, Huppertz B. Endovascular trophoblast invasion: implications for the pathogenesis of intrauterine growth retardation and preeclampsia. Biol Reprod. 2003;69(1):1-7.

22. Brameld KJ, Dickinson JE, O'Leary P, Bower C, Goldblatt J, Hewitt B, Murch A, Stock R. First trimester predictors of adverse pregnancy outcomes. Aust NZJ Obstet Gynaecol. 2008;48:529-35.

23. Ravenswaaij VR, Goot TM, Wolf S, Spruijt LM, Visser $\mathrm{GH}$, Schielen PC. First trimester serum PAPP-A and $\mathrm{f} \beta$ hCG concentrations and other maternal characteristics to establish logistic regression based predictive rules for adverse pregnancy outcome. Prenat Diagn. 2011;31:50-7.

24. Spencer K, Cowans NJ, Molina F, Kagan KO, Nicolaides KH. First-trimester ultrasound and biochemical markers of aneuploidy and the prediction of preterm or early preterm delivery. Ultrasound Obstet Gynecol. 2008;31:147-52.

25. Spencer $\mathrm{K}$, Cowans NJ, Avgidou $\mathrm{K}$, Molina $\mathrm{F}$, Nicolaides KH. First-trimester biochemical markers of aneuploidy and the prediction of small-for-gestational age fetuses. Ultrasound Obstet Gynecol. 2008;31:15-19.

26. Spencer K, Cowans NJ, Avgidou K, Nicolaides KH. Firsttrimester ultrasound and biochemical markers of aneuploidy and the prediction of impending fetal death. Ultrasound Obstet Gynecol. 2006;28:637-43.

27. Kuc S, Wortelboer EJ, Rijn BB, Franx A, Visser GH, Schielen PC. Evaluation of 7 serum biomarkers and uterine artery Doppler ultrasound for first-trimester prediction of preeclampsia: a systematic review. Obstet Gynecol Surv. 2011;66(4):225-39.

28. Bilagi A, Burke DL, Riley RD, Mills I, Kilby MD, Morris KR. Association of maternal serum PAPP-A levels, nuchal translucency and crown-rump length in first trimester with adverse pregnancy outcomes: retrospective cohort study. Prenat Diagn. 2017;37(7):705-11.

29. Gagnon A, Wilson RD, Audibert F. Obstetrical complications associated with abnormal maternal serum markers analytes. J Obstet Gynaecol Can. 2008;30:918-49.

30. Krantz D, Goetzl L, Simpson JL, Thom E, Zachary J, Hallahan TW, et al. Association of extreme firsttrimester free human chorionic gonadotropin beta,pregnancy-associated plasma protein A, and nuchal translucency with intrauterine growth restriction and other adverse pregnancy outcomes. Am J Obstet Gynecol. 2004;191:1452-8.
31. Dugoff L. First- and second-trimester maternal serum markers for aneuploidy and adverse obstetric outcomes. Obstet Gynecol. 2010;115(5):1052-61.

32. Kavak ZN, Basgul A, Elter K, Uygur M, Gokaslan H. The efficacy of first-trimester PAPP-A and free beta hCG levels for predicting adverse pregnancy outcome. J Perinat Med. 2006;34:145-8.

33. Mithil P, Panchanadikar TM, Girija W. Variation of Papp-A level in the first trimester of pregnancy and its clinical outcome. $J$ Obstet Gynecol India. 2014;64(2):116-9.

34. Gagnon A, Wilson RD, Audibert F, Allen VM, Blight C, Brock JA, et al. Obstetrical complications associated with abnormal maternal serum markers analytes. J Obstet Gynaecol Can. 2008;30(10):918-32.

35. Halscott TL, Ramsey PS, Reddy UM. First trimester screening cannot predict adverse outcomes yet. Prenat Diagn. 2014;34(7):668-76.

36. Morssink LP, Kornman LH, Hallahan TW, Kloosterman MD, Beekhuis JR, Wolf BT, et al. Maternal serum levels of free beta-hCG and PAPP-A in the first trimester of pregnancy are not associated with subsequent fetal growth retardation or preterm delivery. Prenat Diagn.1998;18(2):147-52.

37. Leung TY, Chan LW, Leung TN, Fung TY, Sahota DS, Lau TK. First-trimester maternal serum levels of placental hormones are independent predictors of second-trimester fetal growth parameters. Ultrasound Obstet Gynecol. 2006;27:156-61.

38. Smith GC, Stenhouse EJ, Crossley JA, Aitken DA, Cameron AD, Connor JM. Early pregnancy levels of pregnancy associated plasma protein $\mathrm{A}$ and the risk of intrauterine growth restriction, premature birth, preeclampsia, and stillbirth. J Clin Endocrinol Metab. 2002;87:1762-7.

39. Dugoff L, Hobbins JC, Malone FD, Porter TF, Luthy $\mathrm{D}$, Comstock $\mathrm{CH}$, et al. First-trimester maternal serum PAPP-A and free-beta subunit human chorionic gonadotropin concentrations and nuchal translucency are associated with obstetric complications: a populationbased screening study (the FASTER Trial). Am J Obstet Gynecol. 2004;191:1446-51.

40. Malik J, Rai P, Das A, Das S. Pregnancy - associated plasma protein A - a level in first trimester and its impact on pregnancy outcome. $\mathrm{Br} \mathrm{J}$ Obstet Gynaecol. 2016;5(8):2680-3

Cite this article as: Lavanya $\mathrm{T}$, Premalatha $\mathrm{R}$, Thakkar NA, Jawahar L, Rajendran PK, Geethanjali $\mathrm{E}$, et al. The role of pregnancy-associated plasma protein- a level in the first trimester of pregnancy and clinical outcome in an urban referral centre. Int J Reprod Contracept Obstet Gynecol 2019;8:3884-8. 